\title{
SMES CAPITAL STRUCTURE DETERMINANTS: EMPIRICAL EVIDENCE FROM KAZAKHSTAN
}

\author{
Samal Kokeyeva \\ Narxoz University, Almaty, Kazakhstan \\ e-mail: samal.kokeyeva@narxoz.kz \\ ORCID: 0000-0001-5772-8893 \\ (C) 2019 Samal Kokeyeva \\ This is an open access article distributed under the Creative Commons Attribution-NonCommercial- \\ NoDerivs license (http://creativecommons.org/licenses/by-nc-nd/3.0/) \\ DOI: 10.15611/fins.2019.3.02 \\ JEL Classification: C23, D24, E22, G32

\begin{abstract}
The purpose of this paper is to study the standard firm-factor determinants on capital structure of small and medium-sized enterprises (SMEs). To this end, we analyzed small and medium sized firms in Kazakhstan, where all sectors were considered. We use panel data methods to investigate the determinants of capital structure for non-financial SMEs in Kazakhstan. This study examines the impact of key determinants such as asset tangibility, size, growth, profitability and tax rate of SMEs. The trade-off theory and the pecking order theory of capital structure guided this study. The results suggest that despite some differences in the influence of factors on the capital structure, most of the determinants presented by the theory of finance appear indeed to be relevant for the Kazakhstan small and medium business sector.
\end{abstract}

Keywords: capital structure, panel data, SMEs.

\section{Introduction}

The study of capital structure choices is one of the most complicated and prolific research areas within finance and has been relevant for over 60 years. Since Modigliani and Miller [1958], economists have advanced a number of theories to explain the variation in debt ratios across firms. The various capital structure studies show that the combination of leverage-related costs and the tax advantage of debt produces an optimal capital structure below 100\% debt financing [Nicos Michaelas et al. 1999]. This question provided the main lines of research in corporate finance which is the study of the determinants of capital structure (e.g. [Bradley et al. 1984; Kester 1986]). Hence the majority of academic interest is focused on the internal determinants of a company's capital structure, and much less on external environment determinants, especially for small and medium-sized enterprises [Rouse, Jayawarna 2006]. However, the external environment determinants such as the characteristics of the business sector within which the company does business, influence the 
financing decisions [Di Pietro et al. 2018] measured as regional development, on capital structure of small and medium-sized enterprises (SMEs). Moreover, the empirical evidence shows a relationship between the sector and the level of debt in SMEs [Nicos Michaelas et al. 1999; Hall et al. 2000].

Most studies in capital structure decisions are based on empirical analyses of large listed companies with developed financial systems [Demirgüç-Kunt 1999; Rajan, Zingales 1995]. However, a few works have been developed for samples of firms from developing countries [Booth et al. 2001]. Emerging markets suggest the need for brand new approaches of analysis. We investigate the determinants of capital structure choice by analyzing the financing decisions of public firms in the major industrialized countries. At an aggregate level, firm leverage is fairly similar across the G-7 countries. We find that factors identified by previous studies as correlated in the cross-section with company leverage in the United States, are similarly correlated in other countries as well. However, a deeper examination of the U.S. and foreign evidence suggests that the theoretical underpinnings of the observed correlations are still largely unresolved [Rajan, Zingales 1995]. The studied firms of developing countries demonstrate that institutional structures influence capital structure decisions and they are radically different from those of more advanced countries. Kazakhstan was chosen for this study because the country has not previously conducted studies on decision-making on the capital structure of firms before. In Kazakhstan as in other countries, the importance of small and medium-sized enterprises (SMEs) for economic growth is well established, and capital availability is considered a precondition for SME investment and survival. At the same time, financing constraints are regarded as the main barrier to company growth. Companies with better access to external capital grow faster [Rajan, Zingales 1995], and the ability to obtain external financing is an important factor in company development. The country has several programs to support and develop SMEs business, and also has a low tax environment for SMEs. The low loan interest rates and corporate tax rates for SMEs in Kazakhstan, when compared to developed countries, provide a unique environment in which finance theories can be tested.

The results show that some firm-factors and the business sector explain a large proportion of the variance of the capital structure of SMEs.

\section{Capital structure theory and evidence}

Several theories have been developed to explain the financing behavior of firms. The static trade-off theory developed by Modigliani and Miller [1958] is one of the earliest capital structure theories. Subsequent literature was paid great attention to the mitigation of the assumptions made by Modigliani and Miller, in particular considering agency costs [Jensen, Meckling 1976; Harris, Raviv 1990] signaling [Ross 1977], asymmetric information [Myers 1984], corporate control considerations, 
and taxes [Bradley et al. 1984]. Contrary to the pecking order theory, net equity issues track the financing deficit more closely than do net debt issues. While large firms exhibit some aspects of pecking order behavior, the evidence is not robust to the inclusion of conventional leverage factors, nor to the analysis of evidence from the 1990s. Financing deficit is less important in explaining net debt issues over time for firms of all sizes [Frank, Goyal 2003; Harris, Raviv 1988], and taxes. This provides the foundation for the other theories and for the researchers to consider the market imperfections on firm value. Though many theories tried to explain the capital structure, a model to determine the optimal capital structure is still a popular area among the finance researchers. The empirical relevance of the trade-off theory has often been questioned. It is widely reported that in the static trade-off theory of capital structure, a more profitable firm is predicted to have a higher leverage ratio [Frank, Goyal 2003]. According to the pecking order theory, a firm's characteristics, are linked to its capital structure [Myers 1984]. Firms may choose external capital sources if they believe that the total cost of accessing it is lower than that of internal sources or if they have no other alternatives [Öhman, Yazdanfar 2016]. The pecking order explains the negative relationship between capital structure and profitability, and why the most profitable firms generally borrow less or more. If they generate sufficient funds from the business operations, they do not need external money for financing activities. That is why they may have a low target debt ratio. A developed financial sector facilitates access to debt, especially for SMEs, given that it channels savings into credit more efficiently.

The empirical verification of the theories on capital structure was carried out via the study of the effect of different company factors. With regard to SMEs, most empirical research verifies that company size is positively related to debt [Di Pietro et al. 2018; Fama, French 1998; Nicos Michaelas et al. 1999]. Although it is true that a few studies have obtained contrary results e.g. [Heyman et al. 2008] or those that are not significant [Rajan, Zingales 1995]. This finding, according to the pecking order theory of capital structure (POT), suggests that firm size helps to resolve the asymmetric information problems between management and external investors. Rajan and Zingales pointed out that the effect of size on equilibrium leverage is more ambiguous: size may also be a proxy for the information outside investors have, which should increase their preference for equity relative to debt, and firm size will be negatively related to debt.

Another factor that influences the firm's debt level is its growth. Myers [1977] argues that growth opportunities can produce moral hazard effects and can push firms to take more risk, thus firms with growth potential will tend to have lower leverage. On the other hand, Michaelas et al. [1999] argue that growth will push firms into seeking external financing as firms with high growth opportunities are more likely to exhaust internal funds and require additional capital.

Managers prefer internal financing to external financing and risky debt to equity [Myers 1984]. In this context, information asymmetries is relevant only for external 
financing, therefore profitable firms have more domestic financing. In accordance with this theory, the internal cash flows are the preferred form of financing new investments, and we should expect a negative relationship between leverage and profitability [Heyman et al. 2008].

The relationship between liquidity and capital structure needs to be considered in view that liquidity has a significant impact on debt ratios. Firms that have high liquidity ratios may have a higher debt ratio due to their greater ability to meet short-term financing [Anuar, Chin 2016].

\section{Data, variables and research methodology}

All the data used in this study has been collected from the Committee on Statistics of Kazakhstan database. This database contains the financial statements of all non-financial companies in Kazakhstan. A total number of 394 firms for 3 years that
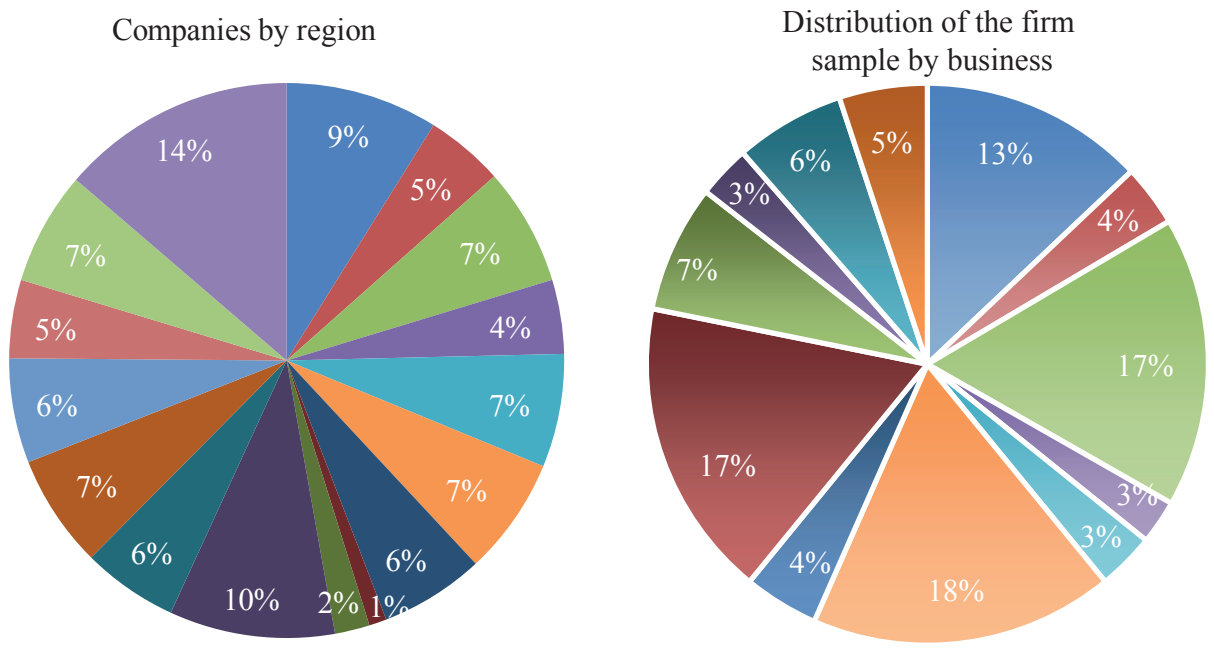

$\begin{array}{ll}\text { Akmola } & \text { Aktobe } \\ \text { Almaty } & \text { Atyrau } \\ \text { East Kazakhstan } & \text { Karagandy } \\ \text { Kostanay } & \text { Kyzylorda } \\ \text { Mangistau } & \text { North Kazakhstan } \\ \text { Pavlodar } & \text { South Kazakhstan }\end{array}$

$\begin{array}{ll}\text { Agriculture, } & \text { Construction } \\ \text { forestry and fishing } & \\ \text { Mining and } & \text { Wholesale and } \\ \text { quarrying } & \text { retail trade } \\ \text { Manufacturing } & \text { Hotels and } \\ \text { industry } & \text { restaurants } \\ \text { Electricity, gas and } & \text { Transport and } \\ \text { water supply } & \text { warehousing }\end{array}$

Fig. 1. Distribution of the company sample by business sector and region

Source: own study. 
satisfied the definitional and data requirements for the research were randomly selected. All firms in the sample are small independent private limited companies, with less than 250 employees. The firms of the sample are present in all business sectors, except the financial sector, and all the 14 regions and the two main cities of Kazakhstan (Figure 1).

The most important sector manufacturing follows the wholesale and retail trade, while Almaty city constitutes the region with the most SMEs in the sample, followed by the North Kazakhstan region.

The dependent variables were chosen based on the literature concerning capital structure. In this study, we used three different measures: total debt, short-term and long-term debt ratios. The short-term debt ratio is defined as short-term debt to total assets. Short-term debt is defined as the portion of the company's total debt repayable within one year. Long-term debt ratio is defined as long-term debt to total assets, it is the total company's debt. The total debt ratio is defined as total debt to total assets. These three variables allow us to examine the influences on the maturity structure of debt as well as the total debt position of the sample companies. There is a likelihood that leverage-related costs of short-term debt may differ from those of long-term debt. While companies may have separate policies with regard to short-term debt, there is likely to be some interaction between the levels of long-term and short-term borrowing [Bennett, Donnelly 1993]. By examining both long-term and short-term measures, we may be able to determine if the factors that influence short-term debt differ from those that determine long-term debt.

Company factors are defined as asset tangibility, size, growth, profitability, liquidity, and effective tax rate. Asset tangibility is defined as fixed assets to total assets (FA/TA), size is defined as the natural logarithm of sales (LOGSIZE). Growth is defined as the growth of total assets (TAt-TAt-1)/TAt-1). Profitability is measured as the ratio between earnings before interest, taxes, amortization, and depreciation and total assets (EBITDA/TA). Effective tax rate is the average tax rate paid by a corporation, defined as the ratio between tax paid and earnings after interest and before taxes (Total Tax/Earnings Before Taxes).

The panel data method brings more advantages compared to the times series and cross-sectional methods. The panel data method is a combination of the times series and cross-sectional method. First, panel data usually provide a large number of data points, increasing the degrees of freedom and reducing the collinearity among explanatory variables, hence improving the efficiency of econometric estimates [Hsiao 1986] . Furthermore, panel data are better able to study the dynamics of adjustment and are better able to identify and measure effects that are simply not detectable in pure cross-sections or pure time-series data. The general regression model of panel data is written as follows: 


$$
\text { Debt }_{i t}=\beta_{0}+\beta_{1} \text { Tangible assets }+\beta_{2} \text { Size }+\beta_{3} \text { Growth }+\beta_{4} \text { Profitability }+\beta_{5} \text { ETR }+\varepsilon_{i t}
$$

where debt ratio represents the leverage ratio for the company " $i$ " ( $i=1-394$ and $t=3), \beta_{x}$ represent the coefficients for each independent variable, $\varepsilon_{i t}$ represent the unknown intercept, that is the error term.

\section{Empirical results and discussions}

The results of the analyses are reported in Table 1 . For each variable, we also compute the ratio of the variable effect on short-term debt ratio to the variable effect on long-term debt ratio, to see to what extent the different explanatory variables influence the maturity structure of debt.

Table 1. Regression coefficients

\begin{tabular}{|l|c|c|c|}
\hline \multicolumn{5}{|c|}{ Variables } \\
\hline & Total debt & Short-term debt & Long-termdebt \\
\hline Constant & 0.978 & 0.201 & 0.776 \\
& $(0.138)^{* * *}$ & $(0.096)^{*}$ & $(0.104)^{* * *}$ \\
\hline Asset tangibility & -0.019 & -0.132 & 0.113 \\
& $(0.053)$ & $(0.037)^{* * *}$ & $(0.041)^{* *}$ \\
\hline Size & -0.106 & -0.005 & -0.101 \\
& $(0.024)^{* * *}$ & $(0.016)$ & $(0.018)^{*}$ \\
\hline Growth & 0.001 & -0.009 & 0.009 \\
& $(0.017)$ & $(0.012)$ & $(0.013)$ \\
\hline Profitability & -0.009 & 0.001 & -0.011 \\
& $(0.003)^{* *}$ & $(0.002)$ & $(0.002)^{* * *}$ \\
\hline ETR & 0.009 & 0.001 & 0.008 \\
& $(0.003)^{* *}$ & $(0.002)$ & $(0.002)^{* *}$ \\
\hline R-Squared & 0.0339 & 0.013 & 0.0694 \\
\hline F- $(p$-value $)$ & $8.17(0.000)$ & $2.83(0.015)$ & $9.489(0.000)$ \\
\hline No of observations & 394 & 394 & 394 \\
\hline
\end{tabular}

Note: Absolute value of $t$-statistics in parentheses, asterisks denote level of significant $* p<0.05$; ** $p<0.01 ; * * * p<0.001$.

Source: own study.

In terms of the particular estimates of regressors, the empirical evidence indicates that in addition to the growth, all the analyzed factors are significantly related to the total debt ratio and long-term debt. In the short-term debt, only asset tangibility is significant. The level of critical significance or p-value for their coefficient indicates a high degree of confidence. As can be seen in Table 1, the growth on short-term and long-term debt ratios is of the opposite sign, indicating that growth influences pertain to the maturity structure of debt as well as to the overall level of debt. We have a positive relation between growth and long-term debt. In terms 
of growth opportunities, SMEs show a positive, but not statistically significant impact of the variable growth on the three measures of debt considered. The positive coefficient of the growth variable is consistent with the pecking order theory. Rapidly growing small firms are likely to have insufficient earnings to finance all of their growth internally. Given the reluctance of small business owners to issue equity, is created by asymmetric information problems and control considerations as well as the relatively higher flotation costs, and fast-growing companies are likely to issue more long-term debt [Nicos Michaelas et al. 1999]. Companies with high growth rates seek external financing and are financed with long-term debt.

The asset tangibility has a negative relation with short-term debt and a positive relation with long-term debt. The negative sign, in this case, could be due to the fact that the SMEs whose short-term debt carries the greatest weight within the total debt have been analyzed and logically the asset structure favors the long-term debt because, as the POT theory postulates, fixed assets can be used as a guarantee. In this sense, SMEs with greater fixed assets (asset structure) use less short-term debt than SMEs with smaller fixed assets [Di Pietro et al. 2018]. They may demonstrate another influential business issue: the maturity matching of assets and liabilities. This means that current assets are financed by short-term debt or trade credit and large fixed assets are financed by long-term loans.

The size has a negative relation with capital structure, which does not correspond to most of the empirical studies. However, Rajan and Zingales [1995] give an alternative argument i.e. that large companies have lower asymmetries between insiders in a firm and the capital markets. That is why large firms should be more capable of issuing informationally sensitive securities like equity and should have lower debt [Rajan, Zingales 1995]. Profitability on short-term and long-term debt ratios is of the opposite sign, which considered both the pecking-order and trade-off theories. The negative correlation between long-term debt and profitability also corresponds to Myers' pecking order theory. Rajan and Zingales found that the relationship between profitability and leverage is negative and this result is consistent with [Titman et al. 1988] who found that the debt level negatively influences the financial performance of the company. This suggests that Kazakhstan's small and medium-sized companies with higher profits prefer to use loans for a short period first rather than loans for a long period. In highly profitable firms there will be more available funds, so they get into less debt than those with low profitability.

The relationship between effective tax rates and the debt ratio is positive. According to the trade-off theory, the company would prefer debt financing due to the tax-deductibility of interest payment. However, this result may be due to the fact that the government subsidizes SMEs and at the same time these companies pay a minimum tax. Because some authors, such as [Pettit, Singer 1985], have pointed out that SMEs are less likely to be profitable, and are therefore less likely to use debt in order to get tax shields because they will not need them, this fiscal approach cannot be applied in the SMEs context. 


\section{Conclusion}

This paper has utilized panel data of a large sample of Kazakhstan SMEs, and empirically examined the implications of the theory of capital structure in the SMEs, by providing evidence on the magnitude, direction and significance of the regression coefficients of the different capital structure determinants. The results suggest that most of the determinants of a capital structure consistent with The pecking order theory and trade-off theory appear indeed to be relevant for SMEs in Kazakhstan. Short debt ratio, long debt ratio and total debt as a dependent variable have been investigated. In order to identify the influent factors that may influence the capital structure decision, the most commonly used factors in the capital structure literature were analyzed as independent variables. The analysis showed some discrepancies with the prior research. The results show a significant relationship with capital structure and independent variables, except growth. As can be seen in Table 2, the effect of asset tangibility and growth on short-term and long-term debt ratios is of the opposite sign, indicating that they influence pertain to the maturity structure of debt as well as to the overall level of debt. As companies grow, they will borrow more long-term debt than short-term debt. This is proved by the coefficient of tangibility, as companies with large fixed assets have more opportunities in obtaining long-term loans. Effective tax rate is positively related with debt. The tax rate is significant, and it is considered as fiscal theory. This may be due to the fact that small companies have a very low tax rate and the government has a special program to develop SMEs by subsiding companies. Most of the results correspond to the pecking-order theory. They suggest that SMEs owners prefer to use retained profits and use loans only when additional finance is essential or use short-term loans for working capital. The current Kazakhstan tax regime provides many incentives to businesses for retaining profits, as corporation tax is charged on profits left in the business. There is fiscal policies, in the form of tax allowances, that provide incentives to retain profits and encourage investment in growth-oriented strategies. Yet the Bank's borrowing requirements for small businesses need to be improved, as long-term loans require collateral in the form of fixed assets, which not all small businesses own. In this regard, small businesses can only obtain short-term loans. Public policy aimed at developing and expanding the capacity of the SME sector should consider making it more attractive for SME owners to reinvest retained profits than to extract them from the firm.

Following on from the findings of this study, the future research might consider investigating further the contradictory finding in profitability, asset tangibility and growth. Future research should investigate generalizations of the findings beyond Kazakhstan and should include longer periods, also incorporating factors such as industrial and geographical effect to understand the financing decisions of companies. 


\section{References}

Anuar H., Chin O., 2016, The development of debt to equity ratio in capital structure model: A case of micro franchising, Procedia Econ. Finance, 7th International Economics \& Business Management Conference (IEBMC 2015), 35, pp. 274-280, https://doi.org/10.1016/S2212-5671(16)00034-4.

Bennett M., Donnelly R., 1993, The determinants of capital structure: Some UK evidence, Br. Account. Rev., 25, pp. 43-59, https://doi.org/10.1006/bare.1993.1005.

Booth et al., 2001, Capital Structures in Developing Countries, J. Finance, 56, pp. 87-130, https://doi. org/10.1111/0022-1082.00320.

Bradley M., Jarrell G.A., Kim E.H., 1984, On the existence of an optimal capital structure: Theory and evidence, J. Finance, 39, pp. 857-878, https://doi.org/10.1111/j.1540-6261.1984.tb03680.x.

Demirgüç-Kunt A.M., Vojislav, 1999, Institutions, Financial Markets, and Firms 'Choice of Debt Maturity, Policy Research Working Papers, The World Bank, https://doi.org/10.1596/1813-9450-1686.

Di Pietro F., Palacín-Sánchez M.-J., Roldán J.L., 2018, Regional development and capital structure of SMEs, Desarro. Reg. Estruct. Cap. Las PYME 18, 37-60, https://doi.org/10.5295/cdg.150530fd.

Fama E.F., French K.R., 1998, Taxes, financing decisions, and firm value, J. Finance, 53, pp. 819-843, https://doi.org/10.1111/0022-1082.00036.

Frank M.Z., Goyal V.K., 2003, Testing the pecking order theory of capital structure, J. Financ. Econ., 67, pp. 217-248, https://doi.org/10.1016/S0304-405X(02)00252-0.

Hall G., Hutchinson P., Michaelas N., 2000, Industry effects on the determinants of unquoted SMEs ' capital structure, Int. J. Econ. Bus., 7, pp. 297-312, https://doi.org/10.1080/13571510050197203.

Heyman D., Deloof M., Ooghe H., 2008, The financial structure of privately held belgian firms, Small Bus. Econ., 30, pp. 301-313, https://doi.org/10.1007/s11187-006-9031-0.

Jensen M.C., Meckling W.H., 1976, Theory of the firm: Managerial behavior, agency costs and ownership structure, J. Financ. Econ., 3, pp. 305-360, https://doi.org/10.1016/0304-405X(76)90026-X.

Kester W.C., 1986, Capital and Ownership Structure: A Comparison of United States and Japanese Manufacturing Corporations.

Myers S.C., 1984, The Capital Structure Puzzle, J. Finance 39, pp. 574-592, https://doi. org/10.1111/j.1540-6261.1984.tb03646.x.

Nicos Michaelas et al., 1999, Financial policy and capital structure choice in the U.K. SMEs: Empirical evidence from company Panel Data, Small Bus. Econ., 12, 113.

Öhman P., Yazdanfar D., 2016, Capital structure dynamics among SMEs: Swedish empirical evidence, J. Risk Finance 17, pp. 245-260, https://doi.org/10.1108/JRF-04-2015-0040.

Pettit R.R., Singer R.F., 1985, Small Business Finance: A Research Agenda, Financ. Manag., 14, pp. 47-60, https://doi.org/10.2307/3665059.

Rajan R.G., Zingales L., 1995, What Do We Know about Capital Structure? Some Evidence from International Data, J. Finance, 50, pp. 1421-1460, https://doi.org/10.1111/j.1540-6261.1995.tb05184.x.

Ross S., 1977, The Determination of financial structure: The incentive-signalling approach, Bell J. Econ., 8, pp. 23-40.

Rouse J., Jayawarna D., 2006, The financing of disadvantaged entrepreneurs: Are enterprise programmes overcoming the finance gap?, Int. J. Entrep. Behav. Res., 12, pp. 388-400, https://doi. org/10.1108/13552550610710162.

Titman et al., 1988, The Determinants of Capital Structure Choice - TITMAN - 1988, The Journal of Finance - Wiley Online Library, http://onlinelibrary.wiley.com/doi/10.1111/j.1540-6261.1988. tb02585.x/abstract (accessed 1.11.18). 


\section{UWARUNKOWANIA STRUKTURY KAPITALU MŚP NA PRZYKŁADZIE SPÓŁEK Z KAZACHSTANU}

Streszczenie: Celem artykułu jest określenie czynników mających wpływ na strukturę kapitału małych i średnich przedsiębiorstw (MŚP). Analizie poddano funkcjonujące w Kazachstanie małe i średnie firmy ze wszystkich branż. Do badań wykorzystano metody panelowe. Zbadano wpływ takich kluczowych czynników, jak: rzeczowe środki trwałe, wielkość spółki i jej zmiany, rentowność, stawka podatku dochodowego. Badania przeprowadzono w kontekście teorii kompromisu oraz teorii hierarchii struktury kapitału. Wyniki pokazują, iż mimo pewnych różnic w oddziaływaniu wybranych czynników, wiele $\mathrm{z}$ nich wywiera istotny wpływ na stan kazachskiego sektora MŚP.

Słowa kluczowe: struktura kapitału, dane panelowe, MŚP. 